\title{
China in Central Asia: The Beginning of the End for Russia?
}

\author{
GARRET MITCHELL \\ George Washington University
}

With China continuing to make economic forays into Central Asia, attention has simultaneously turned to Russia's privileged position in the region. A cursory glance through many articles concerned with the 'Russia - Central Asia - China' dynamic provides a misleading impression that Beijing's strengthened ties with the countries of Central Asia are coming at the expense of Moscow's influence. This paper will show that events, conventionally characterized as breakthroughs in the 'China - Central Asia' relationship in the last four to five years, are in fact part and parcel of larger economic trends that began long before the inking of the energy and trade deals. The reality of China's growing economic influence in Central Asia is not disputed. What this paper will argue is that despite the heralded dislodging of Russia by China, Russia will continue to play a substantial role in the region through a combination of energy, culture, and military bonds that run much too deep for Beijing to sever in the short to medium term.

\section{INTRODUCTION}

For Central Asia watchers 2009 seemed to mark a watershed for the region, for it was then that the spigots on the long discussed Turkmenistan-China natural gas pipeline were at last opened. The $1833 \mathrm{~km}$ pipeline, running through Uzbekistan and Kazakhstan, was heralded not only as a precursor to further regional integration and a feat of engineering - being built in just 18 months - but was also accompanied by discussions of the simultaneous ascendency of China in Central Asia and the end of regional hegemony for Moscow. ${ }^{1}$

That China's influence in Central Asia has grown exponentially in the previous decade is undeniable. 2010 saw Beijing establish itself as the region's primary trading partner negotiating deals worth an estimated $€ 23$ billion ( $\$ 30$ billion), ${ }^{2}$ increasing impressively from only \$572 million in 1992. ${ }^{3}$ The numbers exceeded the EU’s trade figures, but also Russia's, which, alarmingly for Moscow, fell to third place at $€ 17$ billion ( $\$ 22$ billion). ${ }^{4}$

Amid the myriad of figures concerning pipelines and trade, it would be prudent to begin by asking what exactly China seeks in Central Asia. In an area that has seen its importance rise precipitously since the terrorist attacks of 11 September, the attendant dialogue of the region post-2014 falls into speculation of what China's rise means for each country in Central Asia and, indeed, for the Russian Federation.

\footnotetext{
${ }^{1}$ Stephan Blank, 'The Strategic Implications of the Turkmenistan-China Pipeline Project', China Brief, Volume 10, Issue 3 (2010),

<http://www.jamestown.org/programs/chinabrief/single/?tx_ttnews\%5Btt_news\%5D=36010\&tx_ttnews\%5BbackPid\%5D=4 14\&no_cache=1\#.UofDeNJmiSo> [accessed 16 November 2013].

${ }^{2}$ Sebastian Peyrouse, Jos Boonstra and Marlene Laurelle, 'Security and Development Approaches to Central Asia: the EU compared to China and Russia', EUCAM (2012), p. 11,

< http://www.eucentralasia.eu/uploads/tx_icticontent/WP11.pdf> [accessed 11 November 2013].

3 'Central Asia: Report Looks at China's Role in Central Asia', Eurasianet.org (2013),

$<$ http://www.eurasianet.org/node/66607> [accessed 16 November 2013].

${ }^{4}$ Peyrouse, Boonstra and Laurelle, p. 9.

(C) School of Slavonic and East European Studies, University College London, 2014.
} 
In a paper for EUCAM's Security and Development project, Sébastien Peyrouse, Jos Boonstra, and Marlène Laruelle identified China's four main interests in Central Asia, in no order of priority: 1) militating against Uyghur separatism; 2) keeping its western neighborhood stable to decrease the risk of a situation that would necessitate Chinese intervention; 3) gaining access to energy and raw materials; 4) opening up Central Asian markets to Chinese companies and products. ${ }^{5}$

While the first two issues are largely Sino-specific, governments in Central Asia have been keen to exploit Beijing's desire for reliable sources of energy and market share, seeing the burgeoning economic relationship as reciprocally beneficial. For China's Communist Party leadership, energy is critically important in order to maintain stability and growth. Faced with numerous challenges, including environmental degradation and rampant corruption, keeping the lights on and factories producing are essential elements in controlling public disaffection. As over half of Asia's overall energy imports travel through the narrow three-mile-wide Malacca Straights, a significant maritime dispute in South East Asia carries the potential to reverberate far into the Chinese hinterland. Thus Beijing's acquisition of Central Asian energy is not merely sound business policy, but an insurance against a serious threat to its foreign energy links in Africa and the Middle East. ${ }^{6}$ Thus Beijing's current motivations in Central Asia are quite clear, and follow the similar arrangements established all over the world. The countries comprising Central Asia are strategically located on, or very close to, China's western border.

For all of China's progress in Central Asia, it would be premature to believe that it carries enough momentum to dislodge Russia from the traditional position of significance it has maintained with its southern neighbors since the collapse of the Soviet Union. While platitudes about a new Great Game arising in Central Asia make headlines and panel discussions more sensational, the facts surrounding China's prevalence belie the contemporary narrative of its dominance that seems to focus entirely on Turkmen energy contracts (notoriously difficult for all parties involved) and wider regional trade deals.

\section{CASE STUDY}

The following pages will attempt to show that Moscow's status in Central Asia, albeit diminished as a result of nearsighted policies, high energy prices, and a rising China, will nevertheless remain dominant in the short to medium term. This is expected not only on account of legacy ties, but is also supported by the fact that Central Asia represents one of the last locations in the world where Russia exercises soft power. Substantive Chinese inroads into the Central Asian economy should not be discredited. On a bi-lateral basis, however, taking into account the importance of foreign remittances, language, fuel transfers, pipeline networks, and security contacts, Russia continues to husband a privileged regional position.

\footnotetext{
${ }^{5}$ Ibid., p. 11.

${ }^{6}$ Kent E. Calder, The New Continentalism: Energy and Twenty-First Century Eurasian Geopolitics (Yale University Press, 2012), p. 35.

(c) School of Slavonic and East European Studies, University College London, 2014.
} 
To begin, Turkmenistan's 2011 agreement to supply up to 60 billion cubic meters (bcm) of natural gas annually to China, as a result of the completion of the Central Asia-China gas pipeline two years earlier, followed the fashionable narrative of Russian decline in Central Asia. ${ }^{7}$ But seen within the context of previous Turkmen-Russian business negotiations, as well as energy relationships Ashgabat fostered prior to the opening of the Central Asia-China pipeline, the deal need not necessarily be viewed as a bellwether for greater regional change at the expense of Russia.

Much has been written about the bizarre nature of Turkmenistan's orientation during the rule of the late President Niyazov, with one filmmaker going so far as to characterize the country as a 'dictator's Disneyland'. ${ }^{8}$ Yet behind the personality cult of Turkmenbashi replete with rotating golden statues was a savvy energy and foreign policy that provided the small desert nation of around five million people the wherewithal to forge an independent path early on after the fall of communism.

Only four years after achieving independence, Turkmenistan's self-pronounced policy of international neutrality was formally accepted by the U.N. General Assembly in December 1995. ${ }^{9}$ Although this did not preclude Ashgabat from staying within the former Soviet orbit, joining as an unofficial observer nation in the Commonwealth of Independent States, its relations with other member countries have been rocky as evidenced by the establishment of a visa requirement for CIS citizens in $1999 .{ }^{10}$ Exhortations to join additional Russian-led regional organizations have fallen on deaf ears.

In 1997, long before Chinese forays into Central Asia, Turkmenistan opened Central Asia's first pipeline outside the former Soviet space southwards to Iran. ${ }^{11}$ Little notice was taken of these events at the time, and despite a series of proceeding energy agreements between Ashgabat and Tehran, including the January 2010 completion of a second pipeline which expanded Turkmen export capacity to Iran to $424 \mathrm{bcf} / \mathrm{y}$, 12 discussions about Turkmen gas have remained focused on the anticipated zero-sum competition for regional influence between China and Russia. ${ }^{13}$

One could certainly be sympathetic with the perceptions of a Sino-Russian rivalry considering that the completion of the 2009 Central Asia-China pipeline was followed by an agreement between Gazprom and Turkmen officials the year after, increasing the price

\footnotetext{
${ }^{7}$ Tom Balmforth, ‘Turkmenistan: China Export Deal Undercuts Gazprom’s Leverage', Eurasianet.org (2011), <www.eurasianet.org/node/64609> [accessed 16 November 2013].

${ }^{8}$ President for Life (Journeyman Pictures, 2005), <https://www.youtube.com/watch?v=KNJS2-Zv-Tc > [accessed 16 November 2013].

9 'Latest Developments', Embassy of Turkmenistan in Vienna website, <http://www.botschaft-turkmenistan.at/en/news.htm> [accessed 27 April 2013].

${ }^{10}$ Martha Brill Olcott, Anders Aslund and Sherman W. Garnett, Getting it Wrong: Regional Cooperation and the

Commonwealth of Independent States (Carnegie Endowment for International Peace, 2000), p. 19.

${ }^{11}$ Jim Nichol, 'Turkmenistan: Recent Developments and U.S. Interests', in Congressional Research Service Report (2012), p.

7, <https://www.fas.org/sgp/crs/row/97-1055.pdf> [accessed 16 November 2013].

12 'Country Analysis Brief: Turkmenistan', US Energy Information Administration website (2012), p. 8, <http://www.eia.gov/countries/cab.cfm?fips=TX> [accessed 16 November 2013].

${ }^{13}$ Ibid., pp. 7-8.
}

(c) School of Slavonic and East European Studies, University College London, 2014. 
Russia's state-owned energy giant paid for Turkmen gas imports to \$220 - \$250 per thousand cubic meters. ${ }^{14}$

Going back into the business relationship between Turkmen and Russian authorities, a pattern emerges which presents Gazprom's acquiescence to higher prices following the construction of the pipeline to China as not an entirely reactionary move by Moscow hoping to curtail further Chinese inroads into Central Asia. Rather the agreement was part and parcel of a long standing dispute over the price of Turkmen gas that began years prior. Russian purchases of Turkmen, and indeed Central Asian, gas before 2009 were representative of a larger strategy, articulated by the Carnegie Endowment's Martha Olcott, who wrote:

Central Asian reserves provided Moscow with the cushion it would need to maintain its external market position, while Russia's energy industry was first reorganized and then new assets [were] exploited to secure Russia's position in the global energy market for the first half of the $21^{\text {st }}$ century. ${ }^{15}$

Throughout the 1990s and early 2000s, at a time of low energy prices and when Central Asian nations struggled to build up nascent professional capabilities and remained reliant on the Soviet era pipeline infrastructure, the arrangement described by Olcott worked exceedingly well for Russian energy companies. Richard Ericson writes on Gazprom's relations with Turkmenistan as having been 'able to exploit its monopsony position to pay extraordinary low prices,' in a strategy that 'included securing other FSU producers of natural gas to support its supply to Europe, using control over all the export pipelines out of the region'. ${ }^{16}$

For Turkmenistan, this agreement began in earnest in 2003 with a 25 year accord between Gazprom and Turkmen authorities for Russia to purchase natural gas at $\$ 44$ per thousand cubic meters (tcm). ${ }^{17}$ The agreement stipulated that price negotiations could periodically be revisited, something the then President Niyazov used to his full advantage in 2005, when Turkmenistan demanded an increase to $\$ 65$ per tcm and again in September 2006, when Niyazov successfully lobbied Gazprom to raise the export price of Turkmen gas to $\$ 100$ per tcm during 2007-2009.18

\footnotetext{
${ }^{14}$ Vladimir Socor, 'Russia Resuming Gas Imports From Turkmenistan on a Small Scale', The Jamestown Foundation website (2010), < http://www.jamestown.org/single/?no_cache=1\&tx_ttnews\%5Btt_news\%5D=35866> [accessed 16 November 2013].

${ }^{15}$ Martha Brill Olcott, 'Russia, Central Asia, and the Caspian: How important is the Energy and Security Trade-Off?', James Baker III Institute for Public Policy website (2009), p. 14, <http://bakerinstitute.org/files/519/> [accessed 16 November 2013].

${ }^{16}$ Richard E. Ericson, 'Eurasian Natural Gas: Significance and Recent Developments', Eurasian Geography and Economics, Volume 53, Issue 5 (2012), p. 632, <http://www.tandfonline.com/doi/abs/10.2747/1539-

7216.53.5.615? journalCode=rege20\#.UofWj9JmiSo > [accessed 16 November 2013] .

${ }^{17}$ Olcott, p.16.

${ }^{18}$ Sergei Blagov, 'Russia Bows to Gas Pricing Demand', Swiss Federal Institute of Technology website (2006), <http://www.isn.ethz.ch/isn/Digital-Library/Articles/Detail/?ots783=4888caa0-b3db-1461-98b9e20e7b9c13d4\&lng=en\&id=52430> [accessed 16 November 2013].
}

(c) School of Slavonic and East European Studies, University College London, 2014. 
Considering that during this period of fitful negotiations Gazprom was selling natural gas to consumers in Europe at a substantial markup in the range of \$210-230 per tcm, repeated Turkmen entreaties for price hikes in the mid 2000s were not in danger of undercutting Gazprom's bottom line. ${ }^{19}$ Moreover these protracted discussions are indicative of a pattern that contradicts the assumption that Turkmenistan's insistence on market based prices in 20092010, which led to Gazprom agreeing to pay $\$ 220$ - \$250/ tcm, was a direct result of China's pipeline leverage that did not exist before. ${ }^{20}$

The period 2009-2010 is significant, however, in that Russia's policy of benign neglect of Turkmenistan, specifically, and Central Asia generally began to show signs of vulnerability in relation to the Kremlin's regional strategy.

Much of the blame for the Kremlin's perceived and real weaknesses in Central Asia lay with the Russian state itself. At the height of the world economic crisis in 2008-2009 European demand for Russian natural gas atrophied, quickly exposing Russia's brittle economic foundations that relied excessively on hydro carbon exports. Cheap gas from Central Asia, which had always buttressed Moscow's dual approach of subsidizing domestic consumers while sending the remainder to lucrative markets in Central and Western Europe, was suddenly redundant.

When European demand abruptly shrank in 2009 and natural gas prices inevitably fell, Moscow attempted to put the brakes on with regards to the Turkmen gas imports, fearing an oversaturated market would depress prices further. This unilateral and ill-conceived decision taken in April 2009 reduced Gazprom's imports from Turkmenistan substantially, causing a rupture in the Central Asian Center (CAC) pipeline at a location near the Turkmen-Uzbek border. ${ }^{21}$ Whether this event was an impartial mistake or deliberate act of sabotage remains a source of debate on both sides. Regardless of culpability, Russian imports of Turkmen gas didn't resume until almost a year later.

Russia's reduced purchases of Turkmen gas from a high of 41.6 billion cubic meters in 2007 to 10.7 billion cubic meters in 2010 was remarkable. ${ }^{22}$ The result left Gazprom's reputation as a dependable buyer of gas in doubt and caused major financial hindrances for Ashgabat which was reported to have lost a billion dollars a month during the ordeal. ${ }^{23}$ All told, the misfortune is estimated to have cost Turkmenistan one fourth of its annual GDP in 2009. 24

\footnotetext{
${ }^{19}$ Henrik Bergsager, 'China, Russia and Central Asia: The Energy Dilemma', The Fridtjof Nansen Institute website (2012), p. 15, < www.fni.no/doc\&pdf/FNI-R1612.pd> [accessed 16 November 2013].

${ }^{20}$ John Daly, 'Green Eyed Gazprom Attacks Turkmenistan's Natural Gas Resources', Oilprice.com (2011),

<http://oilprice.com/Energy/Natural-Gas/Green-Eyed-Gazprom-Attacks-Turkmenistans-Natural-Gas-Resources.html > [accessed 16 November 2013].

${ }^{21}$ Ibid.

22 'Gas Purchases, Strategy', Gazprom.com, < http://www.gazprom.com/about/production/central-asia/> [accessed 27 April 2013].

23 'Turkmenistan: Desperate for a Gas Market', Forbes.com, 29 April (2010),

<http://www.forbes.com/sites/energysource/2010/04/29/turkmenistan-desperate-for-a-gas-market/ > [accessed 16 November 2013].

${ }^{24}$ Deirdre Tynan, 'Turkmenistan: Gas Flows Again to Russia while Discontent Simmers', Eurasianet.org (2010), <www.eurasianet.org/departments/insight/articles/eav011410.shtm> [accessed 16 November 2013].
}

(c) School of Slavonic and East European Studies, University College London, 2014. 
Under these circumstances, Turkmenistan's appreciation for China's consumer market as an alternative destination for its gas was as much about economics as it was about strategy. It is relevant to note, however, that despite all the problems attributed to the CAC pipeline explosion in April 2009, including China's role as subsequent Turkmen benefactor, Russia continues to be an important transit point for Turkmenistan's energy exports. ${ }^{25}$

Chinese advances into Russia's 'near abroad' have been spurred on in part by a protracted dispute between Moscow and Beijing over the price of energy. Writing a recent article in The Diplomat, Scott Harold and Lowell Schwartz summed up the dilemma facing Russia and China as both seek to gain the upper hand in energy trade negotiations:

In the realm of bilateral energy trade, China's goal is to acquire as much cheap and reliable energy as possible without relying too heavily on any single-nation source, which could be disrupted by an unexpected bilateral crisis. For its part, Moscow wants to retain as much leverage as possible over the price of the natural resources it sells and to avoid becoming dependent upon China as a destination for its energy exports. ${ }^{26}$

While the relationship is flourishing in terms of oil - China is poised to become Russia's largest petroleum export market from 2018 onward - a natural gas agreement, being negotiated without an international pricing scheme, has been exceedingly difficult to finalize. ${ }^{27}$ This has led Chinese leaders to seek sources of energy from a variety of regions, including Central Asia.

Talk of a renewed energy focused 'Great Game' in Central Asia between China, the West, and Russia must be tempered with statistics to give a more contextual picture of Central Asia's contributions to China's overall energy strategy. Looking closely at the numbers, it is apparent that Central Asia accounts for a small fraction of China's overall energy portfolio. According to the U.S. Energy Information Agency, in 2009 natural gas made up just 4 percent of the country's total energy consumption, with oil and coal dwarfing that figure, representing 19 and 70

percent respectively. 28 Moreover, China's leading exporter of oil emanating from Central Asia in 2011 - Kazakhstan which supplied 224,000 barrels per day, was itself surpassed by the Russian Federation, which shipped 395,000 barrels per day eastward. ${ }^{29}$

In light of the speculation concerning long-term European demand, coupled with forecasts that China's internal oil consumption may reach upwards of 17 million barrels per

\footnotetext{
25 'Country Analysis Brief: Turkmenistan', p. 5.

${ }^{26}$ Scott W. Harold and Lowell Schwartz, 'A Russia-China Alliance Brewing?', The Diplomat website (2013), <http://thediplomat.com/2013/04/12/a-russia-china-alliance-brewing/> [accessed 16 November 2013].

${ }^{27}$ Zachary Keck, 'China’s Changing Oil Calculus', The Diplomat website (2013), <http://thediplomat.com/chinapower/chinas-changing-oil-calculus/> [accessed 26 April 2013].

28 'Country Analysis Brief: China', US Energy Information Administration website (2013), <http://www.eia.gov/countries/cab.cfm?fips=CH> [accessed 16 November 2013].

${ }^{29}$ Ibid.
}

(c) School of Slavonic and East European Studies, University College London, 2014. 
day by 2030, Sino-Russian energy cooperation is likely to increase over time..$^{30}$ Indeed, viewing China as a reliable and growing export destination, Russia's elites have called for expanded trade opportunities between the two nations. ${ }^{31}$

With regards to the economic activity in Central Asia, Beijing appears to be employing tactics similar to those used in resource-rich areas like Africa and Latin America. These regions are characterized by their high demand for a 'no strings attached' development assistance, labor, and cheap products.

For the countries of Central Asia, the flood of relatively inexpensive Chinese goods has not only allowed poorer residents in countries like Kyrgyzstan to obtain basic necessities like fruits and vegetables, ${ }^{32}$ but has also spawned a lucrative cross-border trade by enterprising individual merchants in cities like Almaty. ${ }^{33}$ Yet in the area of mutually beneficial trade, China's presence in the region has, fairly or unfairly, attracted criticism from Central Asians sources, which complain of a shrinking domestic manufacturing base, poor quality consumer goods, and the low public esteem of Chinese businessmen. ${ }^{34}$

Part of the problem with Chinese companies operating in Central Asia may lie in what the International Crisis group describes as a '[failure] to connect to their host communities, preferring to concentrate on developing relationships with power brokers in the capitals or, as need be, at the local level' ${ }^{35}$ Whatever the discord is between Chinese business practices and Central Asian residents, the sentiments are not entirely one-sided, with Chinese workers describing Kazakhstan as a 'highly unpleasant place to work', on account of preconceived prejudices against workers from China. ${ }^{36}$

Taking the aforementioned global developments into consideration, the expansion of Chinese trade with Central Asia does not necessarily prefigure the wholesale expansion of Chinese influence over the region. While trade has indeed increased from 1992 levels of $\$ 572$ million to $\$ 30$ billion in 2010, these numbers are commensurate with additional trade associations Beijing has been pursuing. For example, Sino-Japanese trade has risen three-fold since 2000 to more than $\$ 300$ billion and trade with Vietnam grew by $\$ 9$ billion in a single year

\footnotetext{
30 'Rossiya uvelichivaet postavki nefti v Kitai na 9 milionov tonn', Russkaya sluzhba BBC, 25 February (2013), <http://www.bbc.co.uk/russian/business/2013/02/130225_russia_china_gas_dvorkovich.shtml> [accessed 22 February 2014].

${ }^{31}$ Anna Solodovnikova and Natalia Skorlygina, 'Zhyostkih pravil uregulorivaniya ne budet' Kommersant website, < http://www.kommersant.ru/doc/2229666?isSearch=True> [accessed 25 February 2014].

${ }^{32}$ Charles Recknagel, 'Aging Farm Machinery Hampers Central Asian Productivity ', Radio Free Europe/Radio Liberty website (2013), < http://www.rferl.org/content/central-asia-aging-farms/24976547.html> [accessed 16 November 2013].

${ }^{33}$ Ainur Alimova and Antoine Blua, 'On The Road With Kazakhstan's Women Shuttle Traders', Radio Free Europe/Radio Liberty website (2013), < http://www.rferl.org/content/kazakhstan-women-shuttle-traders/24974097.html> [accessed 16 November 2013].

${ }^{34}$ Marlene Laurelle and Sebastien Peyrouse, The Chinese Question in Central Asia: Domestic Order, Social Change, and the Chinese Factor (Columbia University Press, 2012), pp. 168-171.

35 'China's Central Asian Problem', in Asia Report, Number 244 (2013), p. 14,

<http://www.crisisgroup.org/ /media/Files/asia/north-east-asia/244-chinas-central-asia-problem.pdf > [accessed 16

November 2013].

${ }^{36}$ Ibid., p. 15.
}

(c) School of Slavonic and East European Studies, University College London, 2014. 
from 2010-11 to $\$ 36$ billion annually, yet it would be hard to characterize relations between Beijing, Tokyo, and Hanoi in terms of imminent economic takeover. ${ }^{37}$

Geographic proximity will certainly play in China's favor when discussing Sino-Central Asian trade links and there is no doubt that Moscow is financially incapable of matching Beijing's ability to dole out huge loans on favorable terms. In the realm of security influence, however, China has continued to lag behind Russia. ${ }^{38}$ The Shanghai Cooperation Organization (SCO) traces its roots back to an organization first established in the mid 1990's. Described as 'the only multilateral organization that has been set up by China', ${ }^{39}$ ostensibly to substantiate its regional presence, the $\mathrm{SCO}$ has failed to engender the type of dialogue and collaboration Beijing had originally hoped for. Indeed, in the area of drug interdiction, despite 'officials from the SCO states counter drug agencies meet[ing] regularly to discuss the status and prospects of joint efforts against trafficking', ${ }^{40}$ narcotic flows continue unabated out of Afghanistan through Central Asia. ${ }^{41}$

The literature exploring the inherent weaknesses of the SCO is substantial, but it suffices to say that cultural barriers remain a huge impediment to development. There is perhaps no better example of this than the training conducted by Chinese military academies for Central Asian officers which must be conducted in Russian, as both sides share a dearth of knowledge concerning their counterpart's respective languages. ${ }^{42}$ Returning to Turkmenistan, it should also be noted that Ashgabat has thus far refused membership in China's premier Central Asian club, notwithstanding deepened economic ties.

Curiously, the Chinese government has also taken a hands-off approach to military hardware sales. Whereas Central Asian economic and energy opportunities have been of major concern to state-run companies and banks, Beijing has been content to limit regional joint training exercises and cap equipment transfer values at a few million dollars. ${ }^{43}$ The lack of

\footnotetext{
37 'China-Japan Dispute Takes Rising Toll on Top Asian Economies', Bloomberg.com, 09 January (2013), <http://www.bloomberg.com/news/2013-01-08/china-japan-dispute-takes-rising-toll-of-asia-s-top-economies.html> [accessed 16 November 2013]; 'Vietnam Says China Must Avoid Trade Weapon in Maritime Spat', Bloomberg.com, 03 December (2012), < http://www.bloomberg.com/news/2012-12-02/vietnam-says-china-must-avoid-trade-weapon-inmaritime-disputes.html> [accessed 16 November 2013].

${ }^{38}$ Olga Dzyubenk, 'China to expand C.Asian presence with $\$ 10$ bln in loans', Reuters.com, 05 December (2012), <http://www.reuters.com/article/2012/12/05/china-centralasia-idUSL5E8N59DS20121205> [accessed 16 November 2013]; Wenren Jiang, 'China Makes Strides in Energy “Go-out” Strategy', The Jamestown Foundation website (2009), <http://www.jamestown.org/programs/chinabrief/single/?tx_ttnews\%5Btt_news\%5D=35309\&cHash=4c510fe3b9> [accessed 16 November 2013]; Alexander Sodiqov, 'China Boosts Investment in Tajikistan', Central Asia-Caucasus Institute Analyst website (2009), <http://old.cacianalyst.org/?q=node/5141> [accessed 16 November 2013].

${ }^{39}$ Marlene Laruelle and Sebastian Peyrouse, The Chinese Question in Central Asia (Hurst Publishing, 2012), p. 27.

${ }^{40}$ Julie Boland, 'Ten Years of the Shanghai Cooperation Organization: A Lost Decade? A Partner for the U.S ', The Brookings Institution website (2011), p. 13, <http://www.brookings.edu/ /media/research/files/papers/2011/6/shanghai\%20cooperation\%20organization\%20boland/06_s hanghai_cooperation_organization_boland.pdf > [accessed 16 November 2013].

41 'Opiate Flows Through Northern Afghanistan and Central Asia', United Nations Office on Drugs and Crime website (2012), p.7, < http://www.unodc.org/documents/data-and-analysis/Studies/Afghanistan_northern_route_2012_web.pdf> [accessed 16 November 2013].

${ }_{42}$ Peyrouse, Boonstra and Laurelle, p. 13.

43 'China's Central Asian Problem', p. 21.
}

(c) School of Slavonic and East European Studies, University College London, 2014. 
an arms trade is surprising given the reported appetite of nations like Uzbekistan to acquire more modern kit for their security personnel. ${ }^{44}$

We have seen that China's position of strength in Central Asia is not monolithic, yet it is undoubtedly carving out a place for itself in territory Moscow believes to be its backyard. This begs the question: does China's rise necessarily presage the decline of Russia's prevalent position in Central Asia?

If relying on comparisons of trade figures and loan packages, the answer would have to be in the affirmative. But the Russian government can rest assured in the mid-term knowing their position in Central Asia is upheld through significant historical/cultural ties, military alliances, and a unique form of economic leverage. Combined, these links currently outweigh the inroads China has made in Central Asia in the previous decade.

The number of ethnic Russians residing in Central Asia has notably decreased since the collapse of the Soviet Union. Their combined total currently stands at roughly 7 million. The vast majority continues to live in Kazakhstan, with over 4 million Russians, despite a decline in the percentage of the total population. Ethnic Russians make up 12 percent of the population in Kyrgyzstan; 6 percent in Uzbekistan; 4 percent in Turkmenistan; and 1 percent in Tajikistan. 45

Despite the diminished position for ethnic Russians in the Central Asian republics, the Russian language remains central to daily communication in Kazakhstan and Kyrgyzstan where it enjoys constitutional protection and maintains a viable role for the educated elite and foreigners in the larger cities of Uzbekistan, Tajikistan, and Turkmenistan. ${ }^{46}$

A 2010 paper by the Central Asia Data-Gathering and Analysis Team (CADGAT), a joint research project between the Norwegian Institute of International Affairs and the OSCE Academy in Bishkek, Kyrgyzstan, sheds more light on the issue of language in Central Asian cultural life. Their findings provide a picture of a region that has seen steady growth in the use of native languages, but also one in which Russian continues to be an indispensible element. ${ }^{47}$

As an example, CADGAT describes Russian as predominant in the Kazakhstani media landscape, noting that out of 215 radio and television channels a mere five are broadcast in the Kazakh language. ${ }^{48}$ In neighboring Kyrgyzstan, the Russian channel Pervyi (1st Channel) was consistently found to have the largest numbers of viewers in the country. ${ }^{49}$ Further south in Tajikistan, $90 \%$ of foreign films and television shows were found to be translated only in

\footnotetext{
${ }^{44}$ Andrew Kramer, 'As NATO Prepares for Afghan Withdrawal, Uzbekistan Seeks War's Leftovers', The New York Times website, 31 January (2013), > http://www.nytimes.com/2013/02/01/world/asia/uzbekistan-wants-natos-leftovers-fromafghanistan.html> [accessed 16 November 2013].

45 Azad Garibov, 'Russia and Central Asia: Do all Central Asian roads still lead to Russia?', The Journal of Turkish Weekly website, 13 April (2013), < http://www.turkishweekly.net/news/149055/russia-and-central-asia-do-all-central-asian-roadsstill-lead-to-russia.html> [accessed 16 November 2013].

${ }^{46}$ Gulmira Kamzieva and Erkin Kamalov, 'Russian language still important in Central Asia', Central Asia online (2011), < http://centralasiaonline.com/en_GB/articles/caii/features/main/2011/10/26/feature-01> [accessed 16 November 2013].

${ }^{47}$ K. Aminov, V. Jensen, S. Juraev, I. Overland, D. Tyan, Y. Uulu, 'Language Use and Language Policy in Central Asia', Central Asia Regional Data Review, Vol. 2, No. 1 (2010), < http://www.osce-

academy.net/upload/file/language_use and language_policy in_central_asia.pdf $>$ [accessed 23 February 2014].

${ }^{48}$ Ibid., p. 23.

${ }^{49}$ Ibid., p. 25.
}

(c) School of Slavonic and East European Studies, University College London, 2014. 
Russian, while in terms of print, the majority of books were composed in Russian, with the availability of Tajik literature being described as very limited. ${ }^{50}$ Print media in Uzbekistan also showed significant Russian influence. It was estimated that thirty to forty percent of magazines and newspapers in Tashkent were printed in Russian, while nine in ten books in the country were produced in Russian. ${ }^{51}$ Only in Turkmenistan, where the state controls many facets of life, has the Russian language seen a steep decline. ${ }^{52}$ Yet even here Russian remains in vogue among members of the Turkmen state apparatus and business community. ${ }^{53}$

The leadership of Central Asian governments also shares extensive ties with their Russian counterparts in that most cut their teeth in the previous Soviet era bureaucracy, with some, like Kazakh President Nazarbaev and Uzbek strongman Islam Karimov, inheriting their positions of power as a result of being communist party functionaries. Turkmenistan's leader Gurbanguly Berdimuhamedov was a member of the socialist youth organization Komsomol and also attended university for a number of years in Russia. ${ }^{54}$

While a collective Soviet past has not kept Central Asian governments from establishing ties with China and the West, it does provide Russian and Central Asian elites with a level of mutual intimacy that is currently non-existent for Chinese powerbrokers hoping to further consolidate their role in the region.

The familiarity with Russian culture is perhaps one reason for the vast northward flow of Central Asian migrants who are estimated to number approximately 3.5 million of those seeking work in Russia due to a lack of job prospects in their home countries. ${ }^{55}$ While SinoTajik bilateral trade runs over half a billion euros (\$658 million) and Bishkek ranks Beijing as its number one trade partner with bilateral trade just shy of $€ 3.5$ billion ( $\$ 4.6$ billion), these numbers must be considered alongside the annual remittances emanating from the Russian Federation. ${ }^{56}$

According to the World Bank's Migration and Development Brief, in 2011, 49 percent of Tajikistan's GDP consisted of foreign remittances, while in the same year the Kyrgyz Republic relied on 29 percent of its overall GDP from migrant workers. ${ }^{57}$ Foreign money transfers were reported to have made up around 10 percent ( $\$ 4.5$ billion) of Uzbekistan's GDP in 2011.58 Jumping ahead to early 2014, these trends appear to be continuing, as it was recently reported that half of all remittances sourced in Russia flow to Central Asia, with Kyrgyzstan,

\footnotetext{
50 Ibid., p. 26.

${ }^{51}$ Ibid., p. 29.

52 Ibid., pp. 20, 28.

53 Ibid., p. 20.

${ }^{54}$ Andreas Heinrich and Heiko Pleines, Challenges of the Caspian Resource Boom (Palgrave Macmillan, 2012), p. 155.

${ }^{55}$ Garibov, p. 2.

${ }^{56}$ Peyrouse, Boonstra and Laurelle, p. 13.

57 'Migration and Development Brief ', Worldbank.org, Number 19, Box Figure 2 (2012),

$<$ http://siteresources.worldbank.org/INTPROSPECTS/Resources/3349341288990760745/MigrationDevelopmentBrief19.pdf

$>$ [accessed 16 November 2013].

${ }^{58}$ Daria Anichkova, 'Central Asia’s Migrant Headache', (Carnegie Endowment for International Peace, 2012),

<http://carnegieendowment.org/ieb/2012/06/21/central-asia-s-migrant-headache/c41a> [accessed 16 November 2013];

'Country at a Glance: Uzbekistan', Worldbank.org (2011), <http://www.worldbank.org/en/country/uzbekistan> [accessed 16 May 2013].
}

(c) School of Slavonic and East European Studies, University College London, 2014. 
Uzbekistan, and Tajikistan receiving the lion's share of those money transfers. ${ }^{59}$ Returning to the Chinese bilateral trade figures for a moment, when comparing the dollar amount of total trade versus Russian sourced remittances in side by side analysis, Chinese economic dominance comes into question.

In 2011, Tajikistan's total GDP was approximately $\$ 6.5$ billion ${ }^{60}$, meaning Sino-Tajik trade (\$658 million) comprised around 10 percent of Tajikistan's Gross Domestic Product. Compare this to the almost 50 percent of GDP which came from Russian-sourced remittances. Uzbek remunerations of $\$ 4.5$ billion also far surpassed trade between Tashkent and Beijing, which totaled approximately $\$ 2.4$ billion the previous year. ${ }^{61}$ Among the Central Asian nations, Kyrgyzstan, with a GDP of around $\$ 6.2$ billion, is the only one that could be considered to have a dependent trade relationship with Beijing.

In terms of percentage of the population employed as migrant workers in the Russian Federation (and to a much lesser extent Kazakhstan), Central Asia appears highly reliant on north-south labor flows. At the peak in the years between 2004 and 2008, 2.5 million Uzbeks, 1.5 million Tajiks, and 800,000 Kyrgyz were reported to have left their homes in search of northern work, the majority ending up in Russia, many of whom ultimately found jobs in a booming construction sector. ${ }^{62}$

Any discussion on Russia's economic influence in Central Asia must also consider the implications of the recently established Customs Union (CU). This entity, formally launched in 2010 as an agreement between the governments of Russia, Belarus, and Kazakhstan, seeks to create a single economic space among the three nations. With a set of agreed upon import tariffs, common rules related to documentation, and the elimination of some internal border controls, the hope is to foster regional assimilation through streamlined processes by which goods and people between CU member states can move. ${ }^{63}$ Its goal is to eventually draw more nations into the fold, thus increasing its economic power to act as a balance against entities like the EU. Having only been up and running for a few years, it is premature to say if it will portend greater regional integration, with Moscow serving as the guiding vehicle. At the moment it appears that Tajik and Kyrgyz entry into the Customs Union are the most likely in the short term, with both governments seeming bullish about their prospects. Tajikistan's Ministry of Economic Development and Trade has said that '[t]he admission of Tajikistan to the Customs Union will be a significant step towards economic integration with Russia and

\footnotetext{
59 'Polovina perevodov deneg iz Rossiyi uhodit v strany Srednei Aziyi', Izvestiya.ru, 21 Feburary (2014), < http://izvestia.ru/news/566273> [accessed 21 February 2014].

60 'Country at a Glance: Tajikistan, 2011', Worldbank.org (2013), <http://www.worldbank.org/en/country/tajikistan> [accessed 16 May 2013].

${ }^{61}$ Peyrouse, Boonstra and Laurelle, p. 13.

62 'Central Asia: Migrants and the Economic Crisis', International Crisis Group Asia Report Number 183 (2010), p. 1, <http://www.crisisgroup.org/ /media/Files/asia/centralasia/183\%20Central\%20Asia\%20Migrants\%20and\%20the\%20Econo mic\%20Crisis.pdf> [accessed 16 November 2013].

${ }^{63}$ Rilka Dragneva and Kataryna Wolczuk, 'Russia, the Eurasian Customs Union and the EU: Cooperation, Stagnation or Rivalry?', Chatham House Briefing Paper (2012), pp. 4-7,

〈http://www.chathamhouse.org/sites/default/files/public/Research/Russia\%20and\%20Eurasia/0812bp_dragnevawolczuk.pdf $>$ [accessed 23 February 2014].

(c) School of Slavonic and East European Studies, University College London, 2014.
} 
other Customs Union members'.64 Former acting President of Kyrgyzstan Rosa Otombaeva also commented in a 2011 speech on the possibility of Bishkek's accession, saying that Kyrgyz entry 'is highly important to us' 65

Certainly President Putin has not been averse to leveraging the economic wedge of Central Asian remittances in his quest for new Customs Union members. Speaking at the Russian state of the nation address in 2012, Putin made it clear that citizens of Custom Union nations hoping to enter the Russian Federation would not be subject to travel document enhancements that are scheduled to be in place by 2015.66

The cultural and economic links Russia retains in Central Asia are real and extensive, but considering that Chinese trade and investment have begun to surpass levels that took Russia two-hundred years to establish and nurture should certainly give Moscow cause for concern. Yet in the two other spheres mentioned earlier, security and energy, Central Asia remains firmly placed in the Kremlin's orbit.

\section{CONCLUSION}

In Central Asia, energy, economics, and security are often mentioned as three disparate issues with a common denominator. We return again to Sino-Turkmen energy cooperation to see what that relationship has meant for Russia in the wider framework of its regional energy interests.

Following an agreement signed in June 2012 between Turkmenistan's national gas company and the CNPC, future Turkmen gas deliveries are slated to eventually reach 2.3 trillion cubic feet/ year. ${ }^{67}$ This development, coupled with the thirty-five year production sharing agreement between Turkmenistan and China which confers on the CNCP the status of 'the only foreign company with direct access to an onshore development' in Turkmenistan, is indicative of Ashgabat's outlier status among its neighbors concerning energy relations with China. 68

Turkmenistan aside, it is apparent that Moscow is still the dominant regional energy player. Kazakhstan's two largest oil pipelines with a combined export capacity of 1.42 million bpd both terminate on Russian territory - in Novorossiysk and Samara, respectively. ${ }^{69}$ This is

\footnotetext{
${ }^{64}$ David Trilling, 'Putin's Advance Team Preps Tajikistan for Customs Union', Eurasianet.org (2012), <http://www.eurasianet.org/node/65968> [accessed 16 November 2013].

65 'Kyrgyzstan: The Customs Union Cometh', Eurasianet.org (2011), <http://www.eurasianet.org/node/62987> [accessed 16 November 2013].

${ }^{66}$ David Trilling, 'Putin to Central Asia: Join Customs Union, Nudge Nudge, Wink Wink', Eurasianet.org (2012),

$<$ http://www.eurasianet.org/node/66290> [accessed 16 November 2013].

67 Nichol, 'Turkmenistan: Recent Developments and US Interests', p. 8.

68 'Country Analysis Brief: Turkmenistan'.

${ }^{69}$ Jim Nichol, 'Central Asia: Regional Developments and Implications for U.S. Interests', Congressional Research Service Report (2013), p. 42, < http://www.fas.org/sgp/crs/row/RL33458.pdf > [accessed on 23 March 2014].
}

(c) School of Slavonic and East European Studies, University College London, 2014. 
compared to the Kazakh-China pipeline which after a planned expansion will have an export capacity of 400,000 barrels per day. ${ }^{70}$

Tajikistan remains heavily reliant on Russia for domestic energy needs, importing 90 percent of all petroleum products from the Russian Federation, ${ }^{71}$ while neighboring Kyrgyzstan brings in 92 percent of its fuel from Russia. ${ }^{72}$ Uzbekistan, with the region's largest population of 28 million people, consumes most internally produced natural gas but sends more than half of its remaining gas export capacity through Russia. ${ }^{73}$

In classical fashion, the Russian government, unlike their Chinese counterparts, has been able to deftly maneuver in Central Asian energy affairs, economics, and culture to maintain a small yet regionally significant military alliance with its former Soviet partners. It must be said, however, that the Chinese leadership remains wary of extending itself too deeply into any situation that could result in armed conflict, and their lack of engagement in this respect has likely been calculated.

Under the auspices of the Collective Security Treaty Organization (CSTO), Moscow continues to sell military hardware to Central Asia at discounted rates, maintaining 'a near monopoly on arms sales to the region'.$^{74}$ The International Crisis Group notes that through the penury of the Tajiks and Kyrgyz, Russia has retained basing rights in each country, maintaining the 7,000 strong 201st Division in Tajikistan and continuing to control the Kant airbase outside Bishkek. ${ }^{75}$ The former represents one of Moscow's largest foreign troop contingents in the world. ${ }^{76}$

Finally, in 2001 the Russian military, together with Kazakhstan, Tajikistan, and Kyrgyzstan developed a small rapid reaction force headquartered in Kyrgyzstan totaling around 5,000 troops. ${ }^{77}$ This force is yet to be tested in a real security threat scenario and has been the source of criticism that compared it to a paper tiger following outbreaks of revolution and ethnic violence in Kyrgyzstan. But undoubtedly the security cooperation among Russia and its southern neighbors is far ahead of China's military links through the SCO, who's 'obsession with consensus and for maintaining the status quo has hampered [its] effectiveness'. ${ }^{78}$

\footnotetext{
70 'Country Analysis Brief: Kazakhstan', US Energy Information Administration website (2012), <http://www.eia.gov/countries/cab.cfm?fips=KZ> [accessed 16 November 2013].

${ }^{71}$ Konstantin Parshin, 'Tajikistan: Dushanbe Feeling an Economic Squeeze', Eurasianet.org (2011), <http://www.eurasianet.org/node/63364> [accessed 16 November 2013].

72 'Central Asian Nations Feel the Pinch of Dwindling Fuel Supplies As Russia Tightens Supplies', Europeandialogue.org (2011), < http://www.eurodialogue.org/Central-Asian-nations-feel-the-pinch-of-dwindling-fuel-supplies-as-Russia-tightenssupplies> [accessed 21 April 2013].

73 'Country Analysis Brief: Uzbekistan', US Energy Information Administration website (2012), <http://www.eia.gov/countries/cab.cfm?fips=UZ> [accessed 16 November 2013].

74 'China's Central Asia Problem', p. 21.

75 Ibid., p. 21.

76 ‘Tajik Lawmakers Ratify Russian Military Base Lease', Ria novosti website, 01 October (2013), <http://en.ria.ru/world/20131001/183878412/Tajik-Lawmakers-Ratify-Russian-Military-Base-Lease.html> [accessed 01 April 2014].

${ }^{77}$ Nichol, 'Central Asia: Regional Developments and Implications for U.S. Interests', p. 9.

${ }^{78}$ Peyrouse, Boonstra and Laurelle, p.12.
}

(c) School of Slavonic and East European Studies, University College London, 2014. 
The alarmist reaction to China's presence in Central Asia seems to flow from the same narrative that assumes that China, with its hulking land mass, increased military spending, and seemingly inexhaustible supply of human labor, is destined to one day control the world. That Central Asia - a vast, sparsely inhabited area with a wealth of natural resources placed directly west of China's borders - should be consumed by its giant neighbor seems a natural progression of what has been a remarkable journey for the Chinese since economic liberalization began in the late 1970s.

Taken at face value, Chinese investments in Central Asia are indeed outstripping the United States, the European Union, and Russia. Because of the geographic distance in the case of the EU and America, or the shrinking population and lopsided economy of Russia, it is doubtful that any player will be able to match China on a dollar for dollar basis in the coming years.

Yet, as has been discussed, relying only on figures concerning outsized Chinese FDI and bi-lateral loan guarantees masks a much more complex dynamic. Beyond the superficialities, it is clear, that twenty years after the collapse of the Soviet Union Russia's position in Central Asia is far more dominant than is often reported. Pundits may grant that Moscow's security arrangements with Central Asia are more extensive and superior to those held by China, but when discussing energy and economic cooperation the headlines should be more circumspect.

With the exception of Turkmen gas exports and Kyrgyz bilateral trade, China remains eclipsed by Moscow's shadow in Central Asia. Were it not for foreign remittances springing from Russia, the economies of Tajikistan and Uzbekistan would suffer major contractions. Furthermore, without the Russian controlled energy pipeline network, Central Asian states like Kazakhstan would be extremely hard pressed to transport its major commodities to market.

Through the millions of ethnic Russians who still call Central Asia home, as well as the ubiquity of the Russian language and satellite television programs, the Kremlin has been able to maintain a cultural beachhead in former Soviet Asia at little cost. Perhaps aware of the security vulnerabilities that have arisen due to the inability to reach regional consensus, Central Asia's leaders have also been content to rely in their military preservation on Moscow, which is more than happy to assume the role of protector.

If another Great Game is already afoot in Central Asia, China has shown itself to be a worthy competitor, but Russia, with a significant head start, will be hard to catch in the foreseeable future.

This work is licensed under the Creative Commons Attribution-Non-commercial-Share-alike 2.0 UK: England \& Wales License. This license allows for redistribution and alteration, commercial and non-commercial, as long as credit is given to the author. To view a full copy of this license, visit: http://creativecommons.org/licenses/ or send a letter to Creative Commons, 444 Castro Street, Suite 900, Mountain View.

(c) School of Slavonic and East European Studies, University College London, 2014. 